Comparative Philosophy Volume 4, No. 2 (2013): 24-53

Open Access / ISSN 2151-6014

www.comparativephilosophy.org

\title{
MORAL REALISM AND ANTI-REALISM OUTSIDE THE WEST: A META-ETHICAL TURN IN BUDDHIST ETHICS
}

\author{
GORDON F. DAVIS
}

\begin{abstract}
In recent years, discussions of Buddhist ethics have increasingly drawn upon the concepts and tools of modern ethical theory, not only to compare Buddhist perspectives with Western moral theories, but also to assess the meta-ethical implications of Buddhist texts and their philosophical context. Philosophers aiming to defend the Madhyamaka framework in particular - its ethics and soteriology along with its logic and epistemology have recently attempted to explain its combination of moral commitment and philosophical scepticism by appealing to various forms of meta-ethical anti-realism. This paper argues that those attempts do not succeed, even in their own terms. Their emphasis on universal compassion, among other features of their approaches, is difficult to explain normatively so long as it is embedded within an anti-realist framework. Soteriological values - such as enlightenment and liberation - also seem to require a realist account of their normativity. Though many Buddhist philosophers disagree, there is at least one form of Buddhist philosophy, that of the Yogācāra school, that can be interpreted as articulating a metaethical realism of the kind that the broader Mahāyāna tradition (if not other Buddhist traditions as well) seems to require. In closing, I consider some of the implications of clarifying this meta-ethical background for the prospects of fruitful work in comparative ethical theory.
\end{abstract}

Keywords: meta-ethics, comparative ethics, moral theory, moral knowledge, realism, antirealism, relativism, Buddhist ethics, Bodhisattva, Bodhicitta, Dharma, Madhyamaka, Yogācāra, Nirvana, ultimate, soteriology, compassion, normativity

Whenever a contemporary moral theory is used to interpret the ethical reflections of an ancient non-Western religious or philosophical tradition, there are sceptical responses, often directed at the very idea of superimposing a 'theory' - let alone a non-indigenous theory - on complex and heterogeneous ancient writings. This scepticism can be even more acute when it is proposed that an ancient school of

DAVIS, GORDON F.: Assistant Professor, Department of Philosophy, Carleton University, Canada. Email: gordon_davis@carleton.ca 
thought may best be viewed through the lenses of meta-ethics. Whether it should be called 'Western' or not, meta-ethics is arguably even more modern than 'moral theory', with its terms and methods defined mainly within the technical framework(s) of modern analytic philosophy. Nonetheless, I shall argue here that meta-ethics, in a broad and generic sense, is central to important philosophical threads in several ancient Buddhist traditions. I will also argue that the few Buddhist ethicists who have recently begun to address meta-ethics take it in a direction that pulls away from some key Buddhist themes and philosophical emphases - for better or worse, although it so happens that the anti-realist views they favour are beset by internal tensions that ultimately, I contend, lead to insurmountable philosophical difficulties. But before advancing claims about what would qualify as 'key Buddhist themes', it will be important to reflect on some of the divergences and convergences that have marked debates within some of the Buddhist traditions that will concern us here.

Views differ, among Buddhists, about which discourses or texts offer the most definitive accounts of how the Buddha reached and interpreted his enlightenment, and how his subsequent vocation emerged from that experience. In particular, the recounting of his decision to teach and assist others, rather than remain in solitary bliss, is interpreted differently in different traditions. (I shall return to these interpretive divergences in a moment.) Nonetheless, echoing various well-known discourses, both Theravāda and Mahāyāna traditions treat concern for the welfare of others as a brahmavihara - as something that, whatever else this phrase implies, is good, valuable, admirable, and worthy of aspiration.

Buddhist ethicists have increasingly shifted from debating how to formulate Buddhist altruism as a moral theory to debating the meta-ethics of both moral theories and their own moral beliefs. As some Buddhist philosophers had done in other contexts (in epistemology for instance), they now address not only the practical and theoretical forms that a Buddhist ethics of altruism might take, but also a range of complex meta-theoretical questions, such as: Does the insight gained through bodhicitta capture a conventional truth or an ultimate truth? Can a belief about the morally required scope of altruism count as any kind of truth (in the absence of either a platonist metaphysics or an epistemology of rational requirements)? And if not, what is going on when Buddhists or others seek to convince someone of the value of precepts and other moral ideals? When it is suggested that there is neither truth nor ontology at stake because the value is of a practical nature (e.g., therapeutic or instrumental), sceptics will press other questions. What could account for such 'practical' value if this value does not stand in relation to something that is ultimately valuable and that can explain why certain courses of action have more practical value than others? And what could justify any talk of such value, if it turned out that it is not objectively true that the intended result would be good or valuable per se?

These meta-ethical concerns - whether expressed by Buddhists or sceptics - are not primarily about the role of generalist moral principles in Buddhist ethics, and need not concern the authority of canonical ethical pronouncements. Moreover, these concerns are not about the risks and rewards of moral persuasion - they are not meant to raise the question of whether efforts to 'convince' others may lead to dangerously 
conceited forms of moralizing. ${ }^{1}$ Rather, these are questions about how the status of moral teachings is affected by an objective presence or absence of distinctively moral facts that would make it true that something is valuable or worthwhile, or that some course of action is justified.

The central question about what role, if any, a robust notion of truth plays in the understanding and assessment of moral claims is at the heart of the debate over 'moral realism', and has been central in Western philosophy since G.E. Moore, if not since David Hume. Arguably this question, in a somewhat different form, has accompanied discussions of the universal/particular distinction, even as far back as Plato (in fact, especially in contexts where that distinction was construed in a Platonic vein, i.e. where the paradigmatic universal was the form of 'the Good'). It remains an underexplored question, though, whether ancient Buddhist debates about the distinction between ultimate and conventional truth may have had equally significant implications for how Buddhists thought about moral claims and moral insights. ${ }^{2}$

Casual readers of Buddhist texts might presume that the Dharma is replete with normative truths, given the recurring theme of 'noble truths' concerning the right path to an ultimate soteriological goal (a paramartha - sometimes meaning ultimate purpose as well as ultimate truth). But, apart from relatively uncontested claims about the practical efficacy of precept observance, doubts and denials are common among Buddhist philosophers, regarding more elevated claims about an ultimate intrinsic value in precepts, virtues, social engagement or even soteriology itself.

Those doubts may be traceable to the earliest texts in the Buddhist tradition. Canonical sources state that the Buddha was initially unsure whether he owed it to

\footnotetext{
${ }^{1}$ Outside of meta-ethics, moral realism is often assumed to involve some such conceit. But metaethicists are generally careful about distinguishing moral realism from moral dogmatism (let alone any kind of 'moral imperialism'), and often distinguish it from any vindication of even a modest capacity for moral knowledge. Like Plato, with his realism about universals, or Moore, with his realism about axiology, one can be a moral realist, on purely meta-ethical grounds, without claiming to know which norms or principles are correct. With this in mind, it may even be that the robust moral realist is least likely to adopt such dangerous conceits; cf. Cuneo $(2007,16)$. By contrast, consider what - if anything - would restrain a relativist or an emotivist from trying to impose their moral norms, albeit while conscious that these norms have no epistemic authority. This latter consciousness need not restrain them, since they see no reason to treat restraint (or anything else, including even a principle of epistemically informed modesty) as having any moral authority.

${ }^{2}$ Since talk of 'moral truth' can sometimes sound narrow or parochial, I will often speak in what follows of the broader category of 'normative truths'. The category of normative truths is actually broader in one way, but narrower in another way, than most uses of 'moral truth'. Normative truths may include truths about epistemic, ethical, aesthetic or other reasons. In what follows, I will be referring to ethical reasons, but since these may have to do with values or ideals concerning bliss or eudaimonia, rather than moral obligation, this usage is still broader than 'moral' (and notably includes soteriological matters). On the other hand, insofar as some think that 'moral truths' could be truths about which actions fall under certain social standards or customs, then the present use of 'normative truth' is narrower, since such truths primarily involve an assessment of the customs themselves, or of other fundamental ethical criteria. (This also stands in contrast to a common usage of 'normative' in the social sciences, where the term is often used to refer to actual rather than ideal norms.) A truth about the relation between an action-type and a custom, on the other hand, would generally be descriptive, not normative.
} 
others to reveal the insights he had gained (Gethin 2008, 186), raising the possibility that moral questions of that kind are left unanswered even in the midst of complete enlightenment, or even the possibility that there are no moral truths at that ultimate level of truth. Canonical discourses also highlight the simile of the raft (Gethin 2008, 160-61), which was sometimes deployed to portray moral precepts as tools rather than intrinsically important norms (as hypothetical rather than categorical imperatives, so to speak). In the Mahāyāna tradition, the noble truths are sometimes said to be no more than conventional truths; and the precepts are taken to be dispensable for bodhisattvas. Even nirvāna is sometimes said to be a lesser goal than that of engaged wisdom, a wisdom that includes knowing that the importance of being enlightened is no different than the importance of recognizing quotidian norms and expectations (a wisdom known as advayajñāna and/or samatājñāna ${ }^{3}$ ). Chan/Seon/Zen pronouncements can even be disparaging about goals, ideals and the kind of normative reflection that sees moral truth as somehow above and beyond mundane descriptive truths (Dumoulin 191-201; 253-255). ${ }^{4}$

All this raises several large questions, at least two of which are too large for a single paper. Those two overarching questions are: Do Buddhist philosophers in all major traditions tend to reject moral realism? And, if all or even most do accept some form of moral anti-realism, can they coherently integrate moral reflection into Buddhist philosophy, given that the vast majority do see first-order ethics as an important part of Buddhist thought and practice? The first is a question of interpretation; the second a question of philosophical assessment. Here it is easy to narrow the scope of our discussion, for present purposes, by considering the fairly limited - because only recent - literature on Buddhist views in meta-ethics. These recent forays favor moral anti-realism, while defending the practice of Buddhist ethics. In light of the latter stance, I scrutinize (in Section I) how they propose to dispense with moral realism, and argue (in Section II) that they cannot - or at any rate, cannot do so consistently. In the last section, I turn to consider the question of whether all traditions of Buddhist philosophy face similar problems.

In the latter half of the paper, I also consider the implications of moral realism for comparative ethical theory. Moral realism, like anti-realism, is a meta-theory - or rather, a family of meta-ethical theories. Ethical theories, by contrast, are based on general normative claims (and some are based on a single normative claim; e.g. some forms of utilitarianism are based on a single 'utility principle'). One major source of

\footnotetext{
${ }^{3}$ This latter term refers to one of the five forms of gnosis often attributed to buddhas, this one being, in Paul Williams's gloss, "insight into the equality or sameness of all things" (Williams 2009, 102); other forms involve a kind of dynamic engagement with the world that stands in contrast with early conceptions of nirvāṇa.

${ }^{4}$ Dale Wright (2006) suggests that the Zen tradition may have even less interest in morality than this, often marginalizing conventional as well as ultimate moral values. There will not be space here for further discussion of these issues in the Japanese context; but it is worth noting that James Shields (2011) has recently argued that some of - what he too sees as - the moral limitations of Japanese Zen can be overcome via a turn to Madhyamaka-inspired philosophy of language (Shields 2011, 65; cf. 157). My arguments here will raise some doubts about the philosophical viability of that proposal.
} 
debate within Buddhist ethics has been the series of recent attempts at finding a close fit between a familiar ethical theory and one or another Buddhist moral perspective. ${ }^{5}$ Some argue that these attempts are futile, because rather than offering general principles, Buddhism proposes - they suggest - a kind of ethical particularism. ${ }^{6}$ There will not be space here for a full discussion of what the particularist interpretation might imply (if anything) at the meta-ethical level. Many would insist, though, that insofar as particularism is a normative view, it occupies a certain level of discourse along with other ethical theories, and only with (normative) ethical theories. Since this is not the level of meta-ethics, we should expect particularism and moral realism to be compatible. ${ }^{7}$ A moral realist interpretation of Buddhist ethics need not encourage, then, any efforts to shoehorn its ideals and precepts into the framework of a generalist moral theory. Nonetheless, arguably moral realism would have at least one spillover implication, namely that generalist moral theories are at least worth comparing as candidates for moral truth(s), alongside more complex forms of ethical pluralism and particularism. And if some forms of Buddhist ethics turn out to be committed to some kind of moral realism, this might vindicate the kind of comparative ethical theory of which Buddhist particularists tend to be suspicious. There is no single theoretical interpretation of Buddhist ethics that can be vindicated by the meta-ethical inquiries undertaken here; ${ }^{8}$ but there is some prospect of a vindication of comparative work that traces parallels between Western ethical theories and Buddhist traditions of ethical thought. ${ }^{9}$

\footnotetext{
${ }^{5}$ See, e.g., Keown (2001), Clayton (2006), Siderits (2006), and Goodman (2009).

${ }^{6}$ E.g. Hallisey (1996), and Barnhart (2012, 29-33); cf. Velez de Cea (2004). Without presenting it as an interpretation of Buddhist ethics, Jay Garfield (2000) defends some aspects of a form of moral particularism.

Jonathan Dancy (2000 \& 2004) has famously defended both views; but I know of no Buddhist ethicist who does, and on the contrary, Buddhist particularists often seem sceptical about moral realism. In any case, by defining moral realism in terms of moral facts (note the plural) - rather than in terms of 'principle(s)' or (e.g. Kantian) 'law(s)' - we avoid loading moral realism with a bias in favor of principle-oriented or theory-oriented generalism.

${ }^{8}$ Not even the broadest sort of Kantian interpretation, and not even if a kind of 'categoricity' turns out to characterize the normative truths posited in the most promising forms of Buddhist meta-ethics (pace Mādhyamikas, as we will see shortly). The partly Kantian interpretation I have explored elsewhere (Davis (2013)) gains no more support from Buddhist moral realism than a consequentialist or particularist interpretation would.

${ }^{9}$ This comparative project has been challenged by Michael Barnhart (2012), who defends an 'indigenous approach' to Buddhist ethics. A critique of that approach should not necessarily target the particularism that he believes it favors, but rather the relativism with which his approach could easily become entangled - insofar as it seems not only to let every religious and philosophical tradition conceive of ethics in its own way (surely a positive thing, prima facie), but to let none be judged by a 'theory approach', nor judged by any approach, perhaps, that would be conceptually available to all cultures. However, I should emphasize that my doubts about Buddhist anti-realism are not motivated by a wish to vindicate comparative ethical theory; the doubts stand on their own.
} 


\section{MORAL ANTI-REALISM IN THE MADHYAMAKA REFLECTIONS OF FINNIGAN, TANAKA AND GOODMAN}

Discussions of Buddhist ethics have sometimes noted a worry about a potential gap between the 'is' revealed by yathā-bhüta-dassana / darśana ('seeing things as they are') and the 'oughts' associated with the fourth noble truth (that we ought to reduce suffering, and that, among other things, precepts against harming others ought to be followed). ${ }^{10}$ Rarely, though, have writers on Buddhist ethics attempted to scrutinize or analyze 'ought' or related concepts (such as kusala) in ways that are overtly metaethical. But recently, Buddhist philosophers have begun to tackle meta-ethics more explicitly and more directly. For the first time, for example, a Buddhist philosopher has addressed what is explicitly called 'Buddhist meta-ethics' - in a paper by that very name, by Bronwyn Finnigan (Finnigan 2010).

Finnigan touches on the moral realism/anti-realism debate while focusing on certain other problems that I will discuss briefly by way of a prelude to that debate. I believe her paper shows how central this debate is, albeit indirectly; meanwhile elsewhere she addresses the key problems surrounding moral realism directly - in a couple of papers co-authored with Koji Tanaka. Before turning to those papers, we can start to focus our attention on these problems by pinpointing where they become relevant within the broader set of concerns that Finnigan calls 'meta-ethics'.

The main problem that Finnigan highlights in "Buddhist Meta-Ethics" is principally a problem in the philosophy of action. This is the problem of how an enlightened being whose mind operates non-conceptually can act according to norms or ideals. As I shall suggest, it is similar to problems about the differences between the agency of a perfect phronimos and the agency of merely continent agents problems much discussed by scholars of Aristotelian and Stoic writings on psychology and ethics. Nonetheless, Finnigan is right that moral psychology,

\footnotetext{
${ }^{10}$ Noted, for example, in relation to the Theravāda context by Kalupahana $(1995,37-46)$ and in a Mahāyāna context by Williams (1998, 104-05). Cf. Burton (2004, 55-61). This worry is often salutary. In what follows, I am merely suggesting that the is-ought conundrum does not cut to the heart of the matter in meta-ethics. One way I take the worry to be salutary partly explains why one feature of Buddhist soteriology is largely absent from this paper - namely, the role of karmic causation in Buddhists' pre-nirvanic deliberations. Karmic prospects might be construed as 'reasons' for moral action. But primarily, in those traditions that emphasize them, they represent truths about causal explanation, not moral reasons. It may be to the credit of those who appeal to the moral lessons of Jātaka tales (whether Theravāda or Mahāyāna) that they often treat it as an open question whether negative karmic results should deter a bodhisattva from doing what is impartially justifiable in a moral dilemma, rather than what is optimal in terms of his or her own karma. In any case, truths about karma are not strictly normative truths; if there are truths about karma, they are truths about causal processes (and while they may be deliberatively action-guiding for some, they are not inherently action-guiding for all - in the deliberative sense - and not always justifiably action-guiding, in that sense). These would be truths about what will or would happen, not about what an agent ought to do; and I shall be arguing that even though these truths do not entail normative truths, that is not necessarily a problem for the idea of normative truth.
} 
epistemology and metaphysics come together in these discussions, and in some quite unique ways in the Buddhist context.

Not every intersection of ethics and metaphysics will be a site for meta-ethical debate, however. For example, to show that anattā/anātman has implications for impartiality and the importance of compassion, one needs to combine ethics, metaphysics and epistemology; but rather than posing meta-ethical questions, such efforts typically presuppose some meta-ethical framework or other. By contrast, Finnigan's problem in "Buddhist Meta-Ethics" does raise a key meta-ethical question. The problem is that more than one paradigm of Buddhist epistemology emphasize non-conceptual experience, whereas a plausible framework for analyzing moral deliberation and moral choice would highlight the conceptual abilities of the enlightened agent. Finnigan proposes to bring these together by enriching the conceptual resources of Dharmakīrti's epistemology while reducing the conceptual requirements of moral agency; and this project does raise the question of what form a moral belief must take as the output of moral deliberation.

I suggest, though, that Finnigan's proposal, which is partly psychological and partly meta-ethical, should be considered in light of more purely meta-ethical considerations. The merits of her proposal may turn out to hinge on whether a particular form of moral realism is sound or not. Over the past twenty years or so, one of the most important approaches to defending meta-ethical realism has been John McDowell's Neo-Aristotelian moral realism. ${ }^{11}$ On his view, for an agent to act correctly, she must act on the basis of a moral belief (though often a particular rather than a general belief), and that belief must be true. Roughly speaking, the main Aristotelian premise is that a virtuous agent acts for a reason, a reason she can conceptualize and understand, whether before or after the action; and the moral realist premise (which may or may not also be Aristotelian) is that the validity of the reason rests on an objective normative truth, i.e. a truth about its justificatory status.

If this Neo-Aristotelian moral realism is correct, then we should follow Finnigan in adapting the radical intuitionism of the epistemologies she considers (such as Candrakīrti's and Dharmakīrti's) to the demands of a moral psychology that construes enlightened action as norm-guided in something like the way Damien Keown (2001) outlines, albeit modified in the ways Finnigan suggests. If this form of moral realism is not correct, however, it might well turn out that there are no meta-ethical considerations that could require us to revise their characterization of a buddha's understanding, or any other characterization for that matter. ${ }^{12}$ What Finnigan is

\footnotetext{
${ }^{11}$ As represented by the essays in McDowell's Mind, Value and Reality (1998). In a closely related article, "How Can a Buddha Come to Act", Finnigan acknowledges that the prospects for a view like McDowell's may affect the outcome of her inquiry (Finnigan 2011, 154-55, n. 15). Rather than "bearing only indirectly" (155) on the matter, however, it has a direct and decisive bearing; or so I shall argue.

${ }^{12}$ This is certainly the case if both parts of McDowell's view fail to hold, since abandoning the first idea - that a virtuous agent acts on the basis of a reason - would make it unnecessary to question the mysteriously spontaneous form of engagement that goes along with what I am calling 'radical intuitionism'. But more interestingly, the pressure to abandon the latter might also disappear even if only the second, objectivist part of McDowell's view is judged untenable. We may ask, without that
} 
calling 'meta-ethics' would then be in no position to motivate or guide a reform of epistemology or a remodelling of moral psychology. And in the specific case of a non-deliberative, purely intuitive buddha who nonetheless acts - if not according to plans and purposes then at least in some patterned way - an esoteric or mystical understanding of such agency might be called for, without ethical or meta-ethical constraints coming into play. ${ }^{13}$

With moral realism out of the picture, it will be hard to deny that whatever patterns of action a buddha may initiate, nothing about those patterns would call for justification. That is, neither the decision-making processes nor the acts themselves would require, or even permit of, justification. This would be true, at least, if neither McDowell's nor any other form of moral realism could succeed in making sense of objective normative truths. Until we address questions about normative truth directly, however, it should remain open whether some form of moral realism might be philosophically more cogent - and more consistent with key features of Buddhist ethics - than all known forms of anti-realism. (In section 3, I highlight some alternative realist approaches that rely less on the Aristotelian premises to which McDowell is committed.)

In the meantime, it is unclear how grave a dilemma it is that Finnigan has uncovered. ${ }^{14}$ Part of the uncertainty we might have about this is due to an ambiguity between what would be required to describe a buddha's actions and what would be required to explain their being justified. Our ability to describe buddhahood is indeed likely to be limited, to put it mildly. But our ability or inability to describe actions of the kind Finnigan is interested in (ethically guided actions) may be of little consequence if there is no place for justification or justifiability in a broader philosophy of action. The issues Finnigan raises, which lie at the intersection of meta-ethics and the philosophy of action, depend on the deeper meta-ethical issue of whether there is any objective truth in claims about what is morally or ethically justified. $^{15}$

In fact, Finnigan herself expresses scepticism about the notion of objective justification in two essays coauthored with Koji Tanaka, thereby partially disarming,

objectivism in place, why it would be important to explain even the mere possibility of structured decision-making. Some would say that this possibility does not depend on the existence of objective action-guiding values; but the defence of even a minimal form of intentionality may ultimately depend on a realist conception of normativity (as, e.g., Wedgwood (2007) argues).

${ }^{13}$ The notion of a 'pattern' may itself be problematic here, but some would concede at the very least that a buddha's actions would be patterned so as to allow a response to the pattern of suffering around him or her.

14 Though, admittedly, similar problems are also emphasized (independently) by Paul Williams (1998) and David Burton (2004, 82-86).

${ }^{15}$ This contention has an unexpected affinity, I believe, with Garfield's point, in his critique of Finnigan's "How Can a Buddha Come to Act" (Garfield 2011), that Finnigan presupposes a Davidsonian model of reasons as combinations of belief and desire. Philosophers will disagree about whether Davidson should be characterized as a realist or an anti-realist about non-instrumental practical reasons. Insofar as a case can be made that his view is anti-realist, and insofar as Garfield has correctly identified a key assumption in Finnigan's approach, Garfield's assessment resonates with mine - even though his diagnosis of the ultimately problematic upshot may be different. 
perhaps, the dilemma she considers in "Buddhist Meta-Ethics". In doing so, however, she exposes at least two other dilemmas, which I describe in detail in the next section. Before outlining those problems, I describe their approach and compare it to another Madhyamaka-inspired approach, that of Charles Goodman in his recent book The Consequences of Compassion.

In a contribution to the 'Cowherds' literature, an essay entitled "Ethics for Mādhyamikas", Finnigan and Tanaka begin with a modest interpretive claim. While acknowledging that Mādhyamikas recognize precepts and virtues, they claim that "Mādhyamikas do not address the question of whether they are justified in holding these precepts or virtues" $(2011 \mathrm{~b}, 221)$. "Madhyamaka ethics," they say, "is concerned with practice rather than justification" (227); it "is distinctive in its explicit focus on the fulfillment of ethical precepts in conduct rather than their justification" (227). Citing the Prāsangika philosopher Patsab, they explain:

[A] Prāsangika is committed to a complete "suspension of normativity"... This is not to abandon all ethical precepts, however. Rather, precepts function as "pragmatic guidelines on how to go on living one's life"... What is the distinction between pragmatic guidelines for living, which do not have normative force, and precepts with normative force? Normativity is grounded in justification, which in turn depends upon argumentation... [But] the activity of justifying ethical precepts is not a practice on the bodhisattva path. $(2011 \mathrm{~b}, 226)$

These initial claims do not explicitly deny that ethical justification is possible, or that moral truth exists in a robust objective form. They suggest a modest position, which might be called 'meta-ethical quietism'. But as we shall see, Finnigan and Tanaka go further, endorsing meta-ethical (and moral) anti-realism, at least as a framework for Madhyamaka thought. (It will be important later to keep in mind that there is a potentially misleading assumption in the claim that "justification... depends upon argumentation". For some moral realists, including Plato and G.E. Moore, the possibility of objective truths about justification does not and cannot depend on anyone's ability to argue persuasively in favor of such truths. Perhaps the purest form of moral realism would say that moral truths are independent of anyone's and everyone's beliefs and desires, like mathematical truths; and if some mathematical truths are bound to be beyond our ability even to formulate them, then a fortiori they would be beyond our ability to reason about their soundness, let alone demonstrate them. On a similar view of moral and other normative truths, there would be no guarantee that we could conclusively establish any specific truths of this 'external' kind.)

Finnigan and Tanaka constructively suggest that their Madhyamaka approach can "expand the domain of ethics to incorporate a concern with the role of an agent's attitudes, dispositions, motivations, and phenomenology for the very possibility of ethical practice and the perfection of virtue" (Finnigan \& Tanaka 2011b, 227). Meanwhile, they draw critical conclusions as well. At first tentatively, they suggest that the Madhyamaka approach involves "an implicit recognition of the limitations of justification" (227). But this recognition cuts deeper. They argue that there cannot be 
the kind of non-relative justification with which I began at the outset of this paper:

[C]ertain strategies [may be] unavailable for justifying ethical precepts. For instance, [Mādhyamikas] would not be able to appeal to actual properties or states of affairs in the world to function as truthmakers. From the standpoint of the ultimate truth, there are no actual properties or states of affairs in the world that could function in this way... Even if ethical precepts cannot ultimately be justified, might they be justified conventionally or as conventions? (223) ... [O]ne might say, while there are no real, ultimately existing properties that can ultimately justify the bodhisattva precepts, these precepts are nonetheless conventionally justified in the context of the bodhisattva path (224) ... The point is that, if we opt for ethical contextualism, the reasons Mādhyamika thinkers can provide for the value of the precepts on the bodhisattva path will not have justificatory status outside of this context. (Finnigan \& Tanaka 2011b, 225)

Though perhaps not as radical as moral non-cognitivism, the view that emerges here combines two paradigms of meta-ethical anti-realism: error theory and relativism. At the level of putative ultimate truth, there are no moral or ethical truths; at this level, an error theory applies. It is erroneous, according to this Madhyamaka approach, to suppose there are properties that could explain such truths. At the level of conventional truth, a form of moral relativism applies. The frames of reference to which valid claims are relative are not necessarily cultural on this approach, as in the best-known varieties of relativism, but would include doctrinal systems, paths, methods and conceptual frameworks - perhaps, indeed, with no limits on what could constitute a relevant (and, so to speak, exculpatory) reference frame. ${ }^{16}$

One feature of this relativism is its holding that a putative reason for an action can be assessed in terms of the action's conduciveness to a given path or end, but ends themselves cannot be rationally assessed per se. Citing Carnap's pragmatist epistemology in another essay, Finnigan and Tanaka develop this form of reasonsinternalism:

[C]onventional grounds [for the choice of a method of communication include] efficiency, fruitfulness and simplicity... For the community whose members aspire toward buddhahood... the question may be the efficacy of what people say and do toward the achievement of awakening. Thus, the important issue here has to do with the "planning and optimisation of the future" of samgha... So a reform of conventional truths is a possibility. Indeed, which conventions best meet our interests and purposes is the 'ultimate' question. (Finnigan \& Tanaka 2011a, 188)

We can presume that 'reform' here means improvement, and not just change.

\footnotetext{
${ }^{16}$ Referring to Patsab - the same Prāsangika figure that Finnigan and Tanaka cite - Georges Dreyfus concludes that such an open-ended relativism may indeed follow from this approach to Madhyamaka analysis (Dreyfus 2011, 112). The open-endedness as to eligible reference frames makes this relativism even more radical than the already problematic, but better-known, forms of historical and cultural relativism. After all, on this approach, no normative principle could legitimately constrain the proliferation of reference frames (each of which insulates adherents from external moral or evaluative judgment, in a sense 'exculpating' anything they do - though of course not vindicating it either).
} 
However, on this approach, nothing can make a reform ultimately a change for the better, so the only guidelines in play are beliefs - or intuitions - about preferred changes, and there is no limit to how beliefs, preferences and conventions might evolve. Meanwhile, the use of 'ultimate' in Finnigan and Tanaka's last remark just reiterates that there is no scope, in their view, for rational or objective assessment of conventions except relative to 'interests and purposes'. (There is allegedly nothing more ultimate than the latter form of assessment, so Finnigan and Tanaka call this relativized assessment 'ultimate', though they presumably mean just that it is the only form of evaluative judgment that is not subjective in the way that our 'interests and purposes' are).

In the next section, I offer a critique of this form of ethical relativism. Meanwhile we have not considered the first-order content of Buddhist ethics, other than noting the central importance of compassion as a key element. Like Finnigan and Tanaka, we would do best here to remain neutral on whether there is some framework for ethical theory that would capture all the key elements of Buddhist ethics. It is worth comparing their meta-ethical approach, however, to one suggested by Charles Goodman, who does defend a particular ethical theory as a basis for Buddhist ethics namely, universalist perfectionist consequentialism. ${ }^{17}$ Like Finnigan and Tanaka, Goodman gives Madhyamaka sources a privileged place, but he develops a detailed analysis of the consequentialism that he takes to be a fundamental criterion of rightness. I will not be disputing either his analysis or his belief that Buddhist ethics should have a robust criterion of moral rightness. But doubts about the role of justification, similar to the ones noted above, arise when we consider Goodman's remarks on meta-ethics.

Goodman refers to three levels of compassion, where consequentialist considerations can operate consciously in decision-making at the first two levels, and then be transcended psychologically at the third level while still playing a normative role in impersonally justifying what an advanced bodhisattva does. "The third form of compassion," he suggests, "depends on a realization of emptiness. Those who have it do not believe any ethical theory at all; indeed, they are not committed to any theory about anything" (Goodman 2009, 6). As he illustrates with famous stories about Vimalakīti, the moral criterion recedes from this higher level of consciousness, no longer posing obstacles to the bodhisattva's unlimited compassion; and yet, the criterion continues to distinguish right from wrong, whether anyone consciously notices or not $(2009,114)$. This latter qualification may seem to presuppose moral realism, but the Madhyamaka approach that Goodman invokes once again puts this in doubt. If the most enlightened being is "not committed to any theory about anything", this implies that he or she is neither consciously committed, nor indirectly committed by virtue of some theory being the correct normative explanation of how he or she acts (i.e. by virtue of such a theory capturing the justification, even when it is not employed or even thought about). The only reason for no commitment of the

\footnotetext{
${ }^{17}$ Goodman $(2009,41)$ prefers the term character consequentialism; and in any case, these terms should not lead us to overlook that his theory is in fact a universalist value-pluralist consequentialism.
} 
latter kind being possible would be that there is no true moral theory, and perhaps more generally, no normative truths at all. The meta-ethical turn has once again left us with a moral error theory, except perhaps with regard to relativized moral claims and even if Goodman's bodhisattva would not invoke that theory either (i.e. relativism), a Buddhist philosopher would seem to have no other option at this point.

Goodman's overall position is potentially more precarious than that of Finnigan and Tanaka, insofar as he defends a robust criterion of rightness, whereas they seemingly have the option of simple moral nihilism. Goodman builds an edifice, so to speak, but in a phantom city; whereas Finnigan and Tanaka seem to have less invested in foundational ethical theory (they might agree that there are only phantom cities; but they abstain from theory-building, despite having carte blanche to do so on the clean slate that such 'cities' offer). It seems doubtful, though, that they would bite the nihilist bullet. And if not, it seems that they, along with most Buddhist ethicists, will need some explanation for why some actions are justified and some are not. If a proposed meta-ethical framework ends up undermining that distinction, however, then philosophically (if not soteriologically) there will be at least a couple of prima facie problems to address here. ${ }^{18}$

\section{COMPASSION (KARUNĀ) AND TWO PROBLEMS FOR MADHYAMAKA ANTI-REALISM}

The two problems I shall introduce here pose challenges, I believe, to both Finnigan and Tanaka on the one hand, and Goodman on the other (and possibly several other Mādhyamika philosophers as well ${ }^{19}$ ). But the first one I take up is perhaps most acute for someone with robust normative commitments of the kind Goodman accepts, and in particular for someone who considers compassion (karunāa) to have genuine moral and soteriological value. ${ }^{20}$ The second one will seem most acute for Finnigan and Tanaka since I will show how their own philosophical framework requires a more robust conception of normativity than they allow for. The first sets out from the prospect of ethical agreement on certain first-order concerns (such as the value of

\footnotetext{
${ }^{18}$ As I note below, I do not have in mind a practical or social problem such as a prospect of increasingly nihilistic attitudes in society and the perceived dangers of such attitudes. I shall be discussing only theoretical problems here.

${ }^{19}$ For another example of someone who is in effect a Mādhyamika meta-ethicist, or at any rate metasoteriologist, see Huntington - who develops a similar combination of error theory regarding ultimate truth and relativism regarding conventional truth (Huntington 1989, 10-15; 125-129) ; and among historic figures, there is Patsab (if Dreyfus's conclusion above is correct), and Candrakīrti (if Huntington's interpretation is correct).

${ }^{20}$ Garfield (forthcoming) makes a cogent case for leaving the term karunā untranslated, noting its conceptual distinctiveness in light of the more passive connotation of 'compassion'. However, my use of the term 'compassion' should be harmless in the present context, since I will focus more on the disvalue of one way of rejecting this whole family of moral emotions (the kind of rejection that is based on an extreme form of egoism), rather than on the positive value(s) concerned - whose value, I note below, can seem torn between a direct and an indirect form (where the indirect form serves something else of intrinsic value, namely general well-being).
} 
compassion); the second scrutinizes the higher-order implications of Madhyamaka theoretical reflections on ethics.

The first problem arises when we consider how widespread is the intuitive moral approval of compassion, and when we scrutinize (a) what sort of deficiency is typically attributed to those who shun this value (and/or suppress related emotions like empathy), and (b) how differently this 'deficiency' would have to be characterized according to realist and anti-realist accounts of the normative basis of moral approval. ${ }^{21}$ To sharpen the problem, though, we can both extend the scope of likely agreement on the relevant value (and the scope of agreement about the corresponding deficiency) and concretize one instance of such agreement with reference to the Buddhist context.

There are some who regard the value of compassion as overly sentimental and weak, and some others who see this value as dispensable because they regard it as utterly subjective. It seems safe to say, though, that it is an even smaller minority of people who ever seriously entertain the idea of total rational egoism - an egoism so total that it not only regards the only justified actions as those that serve the agent's interests, but also regards the indulgence of moral emotions like compassion as counterproductive and thus condemnable. (I speak here of beliefs, not patterns of actual behavior; and we may assume that even fewer people would regularly make decisions based on strictly egoistic criteria. ${ }^{22}$ ) To offer a concrete instance of the countervailing consensus, we might - aptly enough - consider the global community of Buddhists. Among Buddhists, there may be some who accept a form of psychological egoism that explains human action in terms of widespread illusions about ego and personal gain. But there are presumably next to none who would accept so-called rational egoism - that is, egoism as a normative framework that is used to guide all of one's conduct. The consensus that rejects this view within the Buddhist context could hardly be shaken, meanwhile, by differing interpretations of anattāanātman. ${ }^{23}$

\footnotetext{
${ }^{21}$ I put this in terms of those who shun or suppress compassion, rather than in terms of those who lack the capacity for compassion, since it would be reasonable to refrain from moral assessments of the latter - not to mention that it may be the compassionate thing to do. (Compassion might also require sparing the former; and arguably they should be spared assessments involving blame, but not necessarily the kind of assessment that would cite a deficiency that results in the suffering of both the egoists themselves and those around them.)

${ }^{22}$ To fully support this, we would of course need empirical evidence - albeit of such complex kinds that I could not do justice to it here. Prinz (2007, 79-84) and Baron-Cohen (2011, 19-41) cite recent evidence showing how psychologically unrealistic any egoistic explanatory framework would be, except perhaps to explain some exceedingly rare cases. Anecdotally, we might remark on encounters with devotees of the writings of Ayn Rand, who sometimes express something close to a rationalegoist view; but anyone who has discussed ethics with such devotees will also be familiar with the limits of their egoism both in theory and in practice. A more interesting example, along similar lines, would be Nietzscheans - and I discuss that perspective below.

${ }^{23}$ I know of no evidence that any tathaggathagarbha-oriented text - for example any of those that appear to treat Buddha-nature as an exception to anätman - departs from the traditional emphasis on compassion and altruism (i.e. karun̄a , dāna, bodhicitta, etc.). It is true, as Premasiri (1997) and Goodman (2009) note, that some non-Mahāyāna traditions have been accused of explaining moral
} 
In any case, the point here is not just that so few people, inside or outside of Buddhist communities, would contemplate adopting rational egoism; it is not even just that so many consider this sort of attitude to indicate a personal, spiritual and social deficiency. Indeed, there is a risk that a survey of general opinion would make such a deficiency seem to be merely one of being out of step with deeply entrenched expectations. The key point is rather that there is evidently also a cognitive deficiency in anyone who endorses rational egoism; such a person is blind in certain ways - not only blind to the feelings and interests of others, but also blind to certain moral truths. ${ }^{24}$ Though this is not the occasion to fully defend this claim, some considerations that support it will emerge in what follows.

We can safely minimize, for present purposes, the complications that arise from distinguishing how rational egoism would impact behavior, compared to how it would impact thoughts and emotions. Some who are attracted to egoism might argue (i) that guiding our decisions and actions by an egoist criterion leaves some scope for allowing compassion at a purely emotive level, and (ii) that strictly speaking, egoism does not rule out compassion in any case, but simply requires that a rational agent weigh the costs and benefits of compassionate responses in each relevant situation. Arguably, though, the prioritizing of cost-benefit analysis simply precludes the true exercise of compassion, and as for (i), a purely emotive form of attention would always fall short in a cost-benefit analysis, because without a potential connection to decision and action, it will strike the egoist as a waste of mental effort. It is safe to say, then, that rational egoism is incompatible with any kind of robust commitment to compassion as a virtue, value or ideal.

Debating the merits and demerits of rational egoism, however, is part of firstorder ethics, and we are concerned with the implications of all this for meta-ethics. If we grant that Buddhism is non-egoistic, and that Finnigan, Tanaka and Goodman illustrate this by vindicating compassion, what follows, regarding the nature of ethical 'vindication'? Let us suppose that their advocacy of compassion could not just be a skillful means, or a device with other goals in mind. It would then be a sincere effort to persuade others of the value of compassion. I have noted that ethical justification does not depend on the scope for argumentation; rather, the nature of justification determines what is at stake when people do happen to engage in moral argument. Now, suppose these Buddhist philosophers were to offer their best arguments for the value of compassion, and suppose one of their interlocutors is a rational egoist. In engaging with this viewpoint, they need not assume that they can successfully convince this person; they need only aim and hope to have a greater depth of insight on their side, and meanwhile make the best case they can. And the key point is that the 'best case' cannot just be defined instrumentally in terms of attaining some goal

norms in terms of egoist evaluative foundations. Even if the accusation held up, however, this would not support the sort of normative framework just referred to; and in any case, the alleged foundations are presumed to coexist with strong forms of the anattā/anātman doctrine.

${ }^{24}$ As the Pāli Canon puts it, the problem is not merely selfish craving, but also erroneous 'view' (dițthi), in particular sakkāyadițthi (Burton 2004, 41; Gethin 1998, 73; cf. Webster 2005, 167 on the ditți of attavāda). 
via the spread of belief in compassion ${ }^{25}$ (let alone in terms of some non-cognitive criterion such as emotive persuasiveness). Rather, it must partly refer to the sort of case that presents compassion as being valuable per se. $^{26}$

It is important to be explicit about a key premise in the argument just offered. This premise deserves its own name - we can call it the Insufficiency of Skillful Means Thesis. This is the thesis that not every ethical and soteriological claim or ideal or value can be wholly a skillful means. It is compatible with this thesis, though, to grant that it is both actually true and often ethically justified that many doctrines and 'ideals' are wholly and exclusively skillful means. It would also be compatible with accepting the thesis to hope that the moves we make in the more theoretical 'language games' (such as philosophy) would be not only correct in a noninstrumental sense, but also skillful in certain ways that are independent of epistemic correctness. $^{27}$ But C.W. Huntington $(1989,94)$, for example, goes too far when he argues that functioning as a skillful means is sufficient for a philosophical move to qualify as a philosophical insight (because, allegedly, there is nothing else for insight to do or to be). ${ }^{28}$ First of all, there is the problem of how we could accept his claim that ethical and philosophical insights are wholly and exclusively skillful means, given that this implies that his claim is itself merely a skillful means. (The problem stems from its putative status as merely a skillful means; since the claim would no

\footnotetext{
${ }^{25}$ Unless they are content to shift the focus to the telic importance of overall well-being, thought of as something facilitated by - rather than constituted by - virtues such as compassion. I consider this possibility below.

${ }^{26}$ Someone might try to object that these philosophers would not have to defend claims about what is intrinsically valuable, since they could take the shorter route of denying any sort of ego that could be made the focus of egoism (in other words, appealing to anattä/anātman). This would not work, though, against a Nietzschean egoist. Even though Nietzsche can easily inspire a form of 'rational' egoism, he nonetheless rejects the metaphysics of diachronically continuous selfhood (see Nietzsche (1966), Beyond Good and Evil §§ 16-17) - much as Buddhists do. In responding to this kind of egoism, it is hard to see what alternative Buddhists would have other than to say that Nietzsche has overlooked a kind of intrinsic value in the experiences of others, a value not dependent on Cartesian or Kantian conceptions of selfhood or will - overlooking all this, that is, as a result of his (poorly supported) moral anti-realism.

${ }^{27}$ Finding Goodman's defence of consequentialism plausible (despite interpretive concerns I express in "Traces of Consequentialism and Non-Consequentialism in Bodhisattva Ethics" (Davis 2013)), I would put even more emphasis than he does on skillful means (upāya) as a key element in a theoretically elaborated Buddhist ethics. In any case, Mahāyāna reflections on the triad of compassion, wisdom and skillful means are profound and persuasive. The question I raise here is only whether every philosophical insight could turn out to be wholly upāya.

${ }^{28}$ I have already mentioned in n. 19 how Huntington (1989) generalizes this to cover all philosophical 'insight'; and in the case of the soteriology of cessation, he says "the concept of a goal is ultimately deconstructed along with any notion of a resolution to the analysis. This points to the important fact that even this most central concern of Buddhist doctrine must be seen as a tool of propaganda - one of the devices of skillful means" $(1989,94)$. If this is the kind of mistake I take it to be, we might hesitate to ascribe it to the Madhyamaka tradition as a whole. In fact, Matthew Kapstein $(2001,217)$ sees some evidence, in at least one Mādhyamika's writings, of treating the soteriological goal's value as based on ultimate truth - which would suggest an interesting contrast with the interpretations discussed above, in section I. His textual evidence is rather slight, however, and it is not clear that he would construe Prajñākaramati's view as realist, or even non-relativist.
} 
longer be epistemically guided, an apt response would not be to philosophically assess the claim, but rather (at best) to appreciate its practical role, even though the former is what would be required before we could accept the claim in a way that suits its philosophical context.) Secondly, we would be trapped in an infinite regress if we asked, of any skillful means, what purpose it serves - because any claim about the purpose would itself be a skillful means, and we would then have to ask about its own purpose, and so on.

The question then becomes, how can we arrive at a proper understanding of the claim that compassion is valuable insofar as this claim cannot be merely a skillful means? Apart from the 'skillful' uses to which it may be put, what would be the point in making this claim if - as the Mādhyamikas above contend - there is no truth of the matter as to whether compassion has intrinsic and objective value, or whether well-being (the loss of which calls for compassion) has intrinsic and objective value? If there can be no truth of the matter, then it would appear that the only point in making such a claim would indeed be instrumental (i.e. practically 'skillful'). But if we accept the Insufficiency of Skillful Means Thesis, the latter cannot be the case, and so truth will inevitably play a role here. Moreover, it cannot just be conventional or relative truth, because those construals would reproduce the problems about how to identify the purposes served by such truths and about whether those purposes are themselves justified. As I argue further in the next section, the robust realism that vindications of compassion seem to require is a realism about ultimate truth.

It could indeed be argued that to treat compassion as having intrinsic value would be to fetishize something that should mainly serve to protect and promote the wellbeing of sentient beings (something whose value may be immeasurable, but nonetheless derivative from this function). If any of the Buddhist philosophers I have cited were to argue this, it would be understandable - but it would just transfer our critical reflections to a consideration of the normative status of well-being, and of the notion of objective truth about its intrinsic value. It should be noted that it would be implicit in this argument itself that well-being has intrinsic value, as Goodman, at least, would agree. But our critical reflections would then focus on how to make sense of the claim that something could have intrinsic value while not really having intrinsic value. We would need to make sense, that is, of how the anti-realist can rule out ultimate value via that last qualification, while avoiding the kind of pure instrumentalism that Goodman rejects. One suggestion would be that something can have 'intrinsic' value in a non-ultimate sense when, and because, some people imbue it with telic value (e.g. by seeking it for its own sake). But this returns us to a relativism that invites the question of what purpose is served by their doing so, and prompts us to raise the question of whether such purposes can have real value within the parameters of this anti-realist suggestion. ${ }^{29}$ Without a role for ultimate normative

\footnotetext{
${ }^{29}$ Within these parameters, the valuer's purpose can itself have 'value' if she forms a further purpose served by the first one; but the ensuing infinite regress sows doubt about whether any real value can be in play here. Standard Western attempts to make this middle position work emphasize desiring (forown-sake) and a role for higher-order desires. Apart from their failure even in the Western context,
} 
truth, it looks like Buddhists may run out of options in meta-ethics that would do justice to the idea that ariyasukha (well-being) has a kind of value that dukkha does not.

Some of the premises I have employed here would no doubt be resisted by defenders of Madhyamaka meta-ethics. ${ }^{30}$ But if we return to Finnigan and Tanaka's essays, we notice that they make several meta-ethical claims that seem tacitly to invoke realist understandings of normativity. The second major problem to consider, then, is endogenous to their work, rather than exogenous (as, perhaps, the intuition that rational egoism is simply false may be exogenous, although they clearly accept that embracing it would be a moral deficiency) $)^{31}$.

If Finnigan and Tanaka were to accept the value-relativism that their reading of Madhyamaka ethics seems to involve, they would be committed to a schema along these lines: on one path or perspective, emptiness supports value $\mathrm{x}$; on another path or perspective, it supports value y; on another, value $z$; and so on, where these values may be mutually incompatible. Some of these values would be incompatible with compassion. (Emptiness itself might be both conceived and valued differently from different perspectives, but I leave aside this added complexity for now.) And there would be no uniquely correct normative implication of emptiness or its apprehension. However, guided by a traditional understanding of the bodhisattva path, they suggest the contrary:

In Mahāyāna ethics, a bodhisattva is one who is actively altruistic or has fully activated bodhicitta. At the heart of bodhicitta is a type of compassion (mahākarunā...) grounded in an apprehension of emptiness. That is, in realizing the interdependence of all sentient beings... bodhisattvas extend their compassion equally to all sentient beings. $(2011 \mathrm{~b}, 229)$

Though they may not have intended to reintroduce a foundational notion of justification here, such a notion slips in, as indicated in the phrase 'grounded in...

once we shift to a Buddhist context there are further problems with the role of desire here. I thank Charles Goodman for sharing his thoughts on this, in correspondence.

${ }^{30}$ They might also be troubled by certain omissions in my account. Mādhyamikas do not merely treat belief in ultimate moral value as erroneous; they add that such belief can also be harmful, resulting in a subtle form of upādāna (attachment) focused on the ideal of 'ultimate value'. The realist views I consider below need not reject this further claim, and it might even lead them to recommend a selfeffacing attitude to the ultimate in practice - though the ultimate would remain in place, at some level of philosophical consciousness. Siderits (2003) considers this problem as it arises in relation to ultimate truth, and likewise leaves it open as to whether this is sufficient grounds for rejecting realism.

${ }^{31}$ It should be emphasized that I have not invoked the idea that rational egoism might be morally or socially dangerous; after all, even if it were dangerous in some way, that would not make it false. The point above is not about our defencelessness in the event of egoism spreading, but rather about the pointlessness of Buddhist ethical values if there turned out to be no real flaw or mistake in adopting an egoist creed. If every person in the world but one became a rational egoist, this one person's call for compassion would be no more than a fist banging on a table, so to speak. (A Humean objection - that there is no chance of so many people becoming so psychologically different than they are now - would address only the 'is' of how people are, not the 'ought' of what they ought not to do; and since Humeans themselves stress this is-ought distinction, they have reason to re-examine this objection.) 
emptiness'. Emptiness is the ultimate truth (or at any rate, an insight that is gained through perfected wisdom), and here it is said to ground an impartial form of compassion. Though a psychological interpretation of this 'grounding' is possible, it is more natural to read "grounded in emptiness" as meaning: uniquely justified by the truth of emptiness. Instead of an open-ended range of mutually incompatible value options, there is at least one value (mahākarunāa) that follows necessarily and justifiably from apprehending the truth of emptiness. And it is difficult not to read this normative implication as deriving a special degree of justification from the fact that ultimate truth (or perfected wisdom) is the starting point.

Finnigan and Tanaka continue as follows:

Sanntideva... distinguishes aspirational from engaged bodhicitta. The first is a sincere aspiration grounded in compassion and an inferential understanding of emptiness and dependent origination to attain awakening for the sake of sentient beings. The second is a spontaneous virtuous engagement mediated by a direct apprehension of emptiness and dependent origination. The second emerges only at the end of the bodhisattva path inspired by the first. While Sanntideva recognizes the value of the aspiration to great compassion and a unified set of bodhisattva virtues grounded in apprehension of the two truths for the cultivation of virtue, he nevertheless recognizes a great difference between aspiring to this great compassion and its actualization. (2011b, 229-230)

And one page later, they add (without the mediation of Sanntideva, and thus perhaps with more explicit endorsement):

The bodhisattva precepts and their role as active values require a robust engagement with the conventional world. (231, my italics)

Even more clearly in this latter claim, the term 'require' is contributing a robust normative element to this account of bodhisattva ethics. The chain of justification seems to be this: an understanding of emptiness requires compassion, and compassion requires moral engagement in the conventional world. (Requirement is clearly not used here in an instrumental sense, and so is presumably used in a different normative sense - that of justifying.) There seems to be no room here for allowing noncompassion-oriented practices to be seen as valid - no room, that is, even to be seen as 'valid' in the sense of valid-relative-to-some-other-understanding. Whatever becomes of relativism, though, there is perhaps room for an error theory. But an error theory about whatever might be thought justified by an understanding or apprehension of emptiness (and in particular an error theory about the justification of compassion) would seem to undermine this whole approach to ethics.

Finnigan and Tanaka's recourse to 'grounding', meanwhile, is surely not a mere slip-up that could have been avoided by a different choice of words. They naturally wish to address how insights gained through enlightenment can guide ethical and soteriological considerations. For the most part, this is only implicit, but as we have just seen, it does surface at times. Part of the trouble here may involve the concept of 'guidance'. (And it is only trouble in terms of the lack of coherence with their overall 
anti-realist approach; without this anti-realism, their thoughts on normative guidance would have been germane to a different approach to Buddhist ethics that I portray favorably in the next section.) I am arguing that this concept of 'guidance' must be normative in this context, and not merely psychological. And I have been arguing that the insight(s) of enlightenment, to be normative, must be action-guiding in a robust justificatory sense. But this is what Finnigan and Tanaka's Mādhyamika appears to rule out.

Something could hardly qualify as a distinctively Buddhist approach to ethics, one might think, if its basic tenets are not somehow justified either in light of a conception of ultimate truth, or in light of an enlightened perspective in which putative ultimate truths are demystified or deconstructed. This should be less controversial than the already uncontroversial observation that something could hardly qualify as a form of Buddhist ethics if it did not include a forthright affirmation of the moral importance of karuna $\bar{a}$. In any case, the prospect of a robust justification of the latter, in light of the former, remains entirely open. Such justification has not been shown to be impossible or incoherent; on the contrary, it may often be presupposed, at least in some common ways of articulating Buddhist moral values.

\section{BUDDHIST MORAL REALISM AND PROSPECTS FOR DEFENDING THE BODHISATTVA PATH}

I have argued that many standard construals of Buddhist ethics tacitly presuppose moral realism, even some that try explicitly to disavow it. But I have not argued in favor of moral realism itself. The status of karuna - in both ethics and soteriology is one of the few constants across Buddhist traditions; its pervasiveness strengthens the claim that Buddhism in general requires moral realism. Yet there is still the option of applying modus tollens to a fuller articulation of that claim. Some might wish, that is, to argue that moral realism is philosophically unacceptable, and therefore, taking a version of the above claim as a given, it might follow that the extravagant vindications of compassion in certain forms of Buddhism would need to be revised or reconceptualized in some way. (Indeed, some might say that this is precisely Madhyamaka's aim: to rectify this with a kind of restorative conceptualization along with a therapeutic kind of deconceptualization.) In any case, a vindication of compassion involves first-order ethics. We should now ask: do all Buddhist texts that broach second-order ethics (i.e. meta-ethics) express or entail moral anti-realism, or are there exceptions in certain traditions of Buddhist philosophy? Are there realist options for Buddhist ethicists? ${ }^{32}$

\footnotetext{
${ }^{32}$ Since, as just noted, I am not offering a defence of moral realism here, this inquiry should not be seen as motivated by a prior commitment to moral realism. It is worth noting, however, the recent turn among philosophers not only towards moral realism in general, but even towards the strong form that accepts the idea of irreducible, non-natural normative truth. The arguably weaker form, meta-ethical naturalism, has been famous for its revival since the pioneering works of Peter Railton, Nicholas Sturgeon and Richard Boyd in the 1980s; but the stronger form has flourished more recently, even among those sometimes presumed least likely to endorse it, such as consequentialists and
} 
We should not underestimate the option of introducing a novel philosophical view (such as an updated form of moral realism) to enrich Buddhist doctrine, even though it has no praecursor in sacred text or in commentary. If philosophers had not been willing to do this at various times in history, Buddhist philosophy would never have evolved. Nonetheless, starting from scratch may not be necessary, since there seem to be at least two strains of moral realism in Buddhist thought, one in the Theravāda tradition and one in the Mahāyāna. Moreover, reflecting on the scope for moral realism in Buddhist ethics opens up a new line of response to Paul Williams's wellknown charge that Śāntideva "destroyed the bodhisattva path" - a worrying charge to Buddhist ethicists, since it focuses on what many regard as a fundamental insight linking anätman to moral impartiality. I close this section by sketching the sort of response that a Buddhist moral realist might offer to Williams.

First, let us consider one Theravāda perspective that may qualify as a form of moral realism. P.D. Premasiri has defended what he calls a naturalist approach to defining moral properties, drawing on themes in the Pāli Canon. ${ }^{33}$ He argues that, in much of the Canon, kusala refers to an objective property - the property of causing beneficial consequences. This analysis is more apt than one might think, because while eschewing metaphysical naturalism, it does indeed correspond to one form of meta-ethical naturalism, on which true moral claims are made true by causal relations.

Such causal relations, however, are samskrta (conditioned) rather than asamskrta (unconditioned). Premasiri is content to confine ethics to the realm of the former. We might worry, however, that these 'conditioned' relations can account only for conditional truths. For example, if a precept is violated, then a psychological effect is produced; and the putative normative truth that corresponds to this fact is the truth that if one wishes to avoid such an effect, then one should honor the precepts. Such conditional truths are better known in ethics as relative truths - in this case, the claim that one should honor the precepts is true relative to a psychological (or soteriological) aim or standard. The conditioned nature of Premasiri's naturalistic truths may thus lead to yet another form of relativism (depending on how the value of aims/standards is explained).

particularists. Kagan (2000 \& 2009) and Parfit (2011) are among those sympathetic with consequentialism. Dancy (2004) defends a particularist form of robust realism, and McNaughton and Rawling (2003) come close to a similar style of particularism. The strong, non-reductionist form of moral realism has also been defended recently by many others who do not follow McDowell's Aristotelian approach - see Audi (2005), Cuneo (2007), Enoch (2011), Hampton (1998), Oddie (2005), Shafer-Landau (2003), and Wedgwood (2007). Unlike those who adopt Railton's (2003) naturalist approach, most of these philosophers conclude that normative reasons, being 'external' reasons, are independent of belief, desire, deliberation and argumentation - and thus all the more objective for being irreducible to any natural properties that may play a role in human psychology.

${ }^{33}$ Premasiri (1997) draws on C. Rhys Davids's (1978) interpretation of normative language in the Pāli Canon. In The Nature of Buddhist Ethics, Keown also recommends a naturalist form of moral realism (albeit with a different understanding of the concept of kusala), but defends it only indirectly, via reflections on the strengths of Aristotle's teleology (Keown 2001, 21, 64, 232). 
Insofar as this remains to be seen, Premasiri's approach may qualify as a proposal for a kind of Buddhist moral realism. ${ }^{34}$ Insofar as the worry is justified, though, we might consider whether there are Mahāyāna perspectives that offer more 'unconditional' forms of moral realism. ${ }^{35}$ We have considered only the Madhyamaka school so far here, and noted its tendency towards moral (and perhaps global) antirealism. But there appear to be the outlines of an alternative, non-reductionist and non-naturalist account of normative truth in some of the texts associated with a different Mahāyāna tradition, the Yogācāra school.

There are two initial steps that help us to see this possibility. First of all, we should take seriously Jay Garfield's conclusion that the Madhyamaka and the Yogācāra philosophical orientations are more at odds than many modern Buddhist traditions have supposed. As Garfield argues, the Yogācāra's quietist dimension is quite different from Madhyamaka's, and its claim to a "mystical intuition of a transcendent realm" reflects a metaphysical realism that Mādhyamikas reject (Garfield 2002b, 182). Secondly, the normative claims we should consider first are not those associated with moral precepts, but those concerning the value of nirvanna. The key normative claim here is axiological rather than deontic - in particular, that nirvāna is a (supremely) worthy goal. Yogācārins believed not only that this goal is so important that it should guide one's life-choices, but also that our affirmations of it are guided by a sense of ultimate justification. The goal and our belief(s) about it, as much as its downstream moral implications, are clearly normative. But did the Yogācārins have a meta-theoretical understanding of this normativity? ${ }^{36}$

Insofar as they thought of nirvāna as inherently normative (anuttara, kuśala, etc.), their reflections on it suggest that they did have such an understanding. David Burton has recently defended something along these lines, echoing Garfield in arguing that Yogācārins made positive claims about ultimate truth that the Madhyamaka tradition did not - and does not - accept. If nirvāna is a worthy goal, this is an ultimate truth,

\footnotetext{
${ }^{34}$ Railton (2003) defends a similar kind of naturalism, while hoping to fend off moral relativism. Horgan and Timmons $(1991,2006)$ - themselves naturalists - have argued that such hopes cannot be sustained, insofar as moral semantics takes that cognitivist-naturalist form.

${ }^{35}$ One could interpret Steven Collins (1998) as showing, in effect, that a Theravāda approach can support axiologically realist claims about nirvāna - similar to the ones I am about to consider. Moving from axiology to morality, Mahāyāna texts seem to stress a more ambitious commitment to moral impartiality and moral engagement. The Mahāyāna treats egoism as an error (like the Pāli suttas (cf. n. 24)), and as an even deeper kind of mistake than that of indulging tanhāa/tṛ̣nāa (perhaps unlike those suttas). Explaining what makes this an error is a major aim of Mahāyāna philosophy, particularly in commentaries rather than canonical texts. (And philosophically, this latter point deserves special notice. We should not expect canonical scripture to address meta-ethics any more than we should expect ancient Greek philosophers to address hermeneutics or metalogic; but many Mahāyānists are willing to let writers such as Sāntideva or Vasubandhu lead the way here, without expecting canonical scripture to have all the answers.)

${ }^{36}$ I switch here to the past tense, because unlike the Madhyamaka, the Yogācāra tradition has no living branch of practitioners who self-identify primarily as Yogācārins.
} 
not a conventional truth; or at any rate so thought Yogācārins such as Vasubandhu. ${ }^{37}$ Their mysticism was starkly opposed to Madhyamaka anti-realism; after all, it is arguably only possible to have a mystical understanding of something when that thing is sufficiently real that human language and concepts might fail to measure up to it. ${ }^{38}$ Both the nature of nirvāna and its value are captured in truths that are ultimate truths. And this value - and its importance to all beings - accounts for objective truths about the value of a bodhisattva's good works (and of their vows to accomplish such works). Since these truths are said to lie beyond our language and even our concepts, this may not be an epistemically robust form of moral realism; but it is a form of moral realism nonetheless, and a form that appears to be non-reductionist and nonnaturalist. $^{39}$

It is also worth emphasizing that, as this implies, Yogācārins were not moral relativists. In fact, their well-known critique of what they saw as Madhyamaka nihilism can be developed into a critique of both meta-normative relativism in general and moral relativism in particular. ${ }^{40}$ Not only do the Yogācārins consider collective nirvāna to be a universally valid ideal; they argue that it could not coherently be considered anything else. Their interest in the latter issue reveals how meta-ethical reflections on truth and objectivity would become integral to their philosophical system. (The former claim, when expressed in terms of the ultimate truth versus conventional truth distinction, is equally meta-ethical, but can also be seen as following from various straightforwardly normative statements, e.g. in sutras rather than philosophical works.) This fundamental non-relativism did not prevent Yogācārins from retaining the Mahāyāna emphasis on upāya (skillful means) and a qualified instrumentalism in ethics; as I explain further below, goal-relative

\footnotetext{
${ }^{37}$ See Burton (2004, 93-95), on Yogācāra's departures from Madhyamaka anti-realism, and on the implications for Yogācāra idealizations of emptiness and nirvāṇa (2004, 131, 142 ff.). Cf. n. 43 below, on Vasubandhu.

${ }^{38}$ Familiar paradoxes about mystical inexpressibility arise here: if the insight is wholly inexpressible, can we describe it as concerning something 'real'? Nonetheless, the point made in the text could be put in formal rather than substantive terms. When we enumerate the various possible forms of antirealism, ineffabilist mysticism is generally not counted among them (contrast scepticism, which has a more contested intermediate status). For instance, it is rightly contrasted with debunking forms of noncognitivism - since, if mysticism were to be considered a form of non-cognitivism, it would have to be called a 'non-cognitivism' that is somehow 'about something'. For that 'something' to be beyond the limits of language and cognition, it could not be a mere projection or presupposition of language or thought (though saying even this much may indeed be paradoxical). In any case, if mysticism is neither scepticism nor anti-realism, it may have to qualify as 'realism' - keeping in mind the qualification in n. 1, inter alia - whatever we might say or refuse to say about the 'real'. I thank one of the journal's anonymous referees for prompting me to clarify this point.

${ }^{39}$ Yogācārins might be reductionist about other things, e.g. the nature of selfhood or personhood, but not about the normative dimension of parinispanna-svabhāva (or, perhaps equivalently, the value of nirvāna). Moreover, if a case can be made that this dimension is irreducibly normative, then the spectre of a problematic 'is-ought' transition can be warded off. Even though moral guidance would be based on normative truth, the truth would not be of a kind that resides problematically on the 'is' side of this divide. By contrast, Premasiri's naturalist approach continues to be haunted by this spectre.

${ }^{40}$ For a summary of the Yogācāra critique of Madhyamaka, see Williams $(2009,86$ ff.).
} 
deliberation is not ethically relativist if the value of the ultimate goal is not relative to varying standards or perspectives. ${ }^{41}$ Meanwhile, however, unlike contemporary forms of moral realism that rely on instrumentalist considerations, the Yogācāra approach involves no ontological commitment to naturalism.

In fact, naturalism may not even be an option for Yogācārins, who have traditionally been interpreted as anti-realists about physical world discourse. Both Garfield and Burton favor this traditional reading. ${ }^{42}$ However, unlike Madhyamaka philosophers, Yogācārins remain metaphysical realists about certain mental phenomena, as well as about some of the moral implications of the value of collective nirvāna. It is the latter point that helps distinguish Yogācāra axiology not only from the Madhyamaka but also from a Theravāda view that combines Premasiri's account of conditioned moral phenomena with an account of unconditioned nirvāna, qua value or ideal. That is, Premasiri's account and the Yogācāra approach might at first seem compatible; but the Yogācāra draws a closer connection between the soteriological value of nirvāna and the moral value of helping all sentient beings attain it, such that insights about the latter (and about the nature of bodhisattva vows) could plausibly be regarded as ultimate truths. ${ }^{43}$

Drawing such a close connection between morality and ultimate truth will be controversial. However, my aim here is simply to show that at least a couple of Buddhist philosophical traditions seem to steer clear of moral anti-realism. Showing this would at least correct any impression that the problems discussed earlier threaten to undermine Buddhist ethics in general. In fact, in closing, it is worth mentioning a possible defence of one major Buddhist moral argument, a defence that is made possible by noting the scope for moral realism in Buddhist ethics. That moral

\footnotetext{
${ }^{41}$ I thank one of the journal's anonymous referees for suggesting that I emphasize how non-relativism (about the status of nirvāna) and pervasive means-ends deliberation can thus be reconciled. It may be only in Madhyamaka philosophy that such a reconciliation is not available, partly for the reasons noted in section I, and partly in light of its Nāgārjunian debunking of nirvāna qua svabhava. I have hesitated, however - e.g. in n. 28 - to generalize about all Madhyamaka philosophy. In fact, it is in a discussion of Madhyamaka soteriology, in Kapstein $(2001,217)$ that we find one of the more intriguing equations of ultimate truth with ethical-cum-soteriological truth. I am not sure the passage Kapstein cites, from Prajñākaramati, really supports this equation; but his suggestion is philosophically promising, and as I am arguing here, would at least be at home in expositions of some other Mahāyāna traditions.

${ }^{42}$ Dan Lusthaus (2002), among others, has challenged this reading. For a summary and critique of these challenges, see Garfield (2002d, 155-159).

${ }^{43}$ The last verse of Vasubandhu's Tri-svabhāva-nirdeśa provides one example: "Through the perception of the radiant / And through achieving the three supreme Buddha-bodies / And through possessing Bodhi: / Having achieved this, the sage will benefit him or herself and others" (Jay Garfield's translation, in Garfield (2002c, 151)). Kochumuttom's translation of the last line is: "seeing the meaning of oneself and others" (Kochumuttom 1982, 126), which may support my construal in terms of moral insight. (Of course, one sees through the self-other distinction, ontologically speaking; but ethically, one can see an 'all' beyond oneself.) In another work, the Madhyānta-Vibhāga-Bhāsya, Vasubandhu says: "Ultimate truth is to be known as existing because of the one fulfilled own-being, only... It is ultimate as an object because Suchness is the object of ultimate knowledge... It is ultimate as an attainment because its attainment is equal to Nirvāna, which is the ultimate aim. It is ultimate as practise, because it is the Path, which has the ultimate aim" (Anacker 1984, 236-237).
} 
argument is based on reasoning that is often presumed central to much of Buddhist thought, but is articulated most explicitly by Śantideva (1995) in his Bodhicaryāvatāra (8: 90-103). Although Sāntideva came from the Madhyamaka tradition, there is a praecursor of his argument in an important Yogācāra text - not surprisingly, since the argument is essentially that anātman (no-self) requires impartial concern for the welfare of all beings. ${ }^{44}$

In his book Altruism and Reality, Paul Williams critiques this argument in a chapter provocatively sub-titled "How Santideva Destroyed the Bodhisattva Path". The Madhyamaka approach as a whole may be one of Williams's targets, but there is nothing specifically Madhyamaka that he singles out as philosophically undermining the bodhisattva ideal. Rather, he identifies the general Buddhist acceptance of anätman (no-self) as being responsible for this. This is not the place for a full discussion of Williams's rich exploration of the philosophical problems that arise here. We should just notice that his position is that a sine qua non of moral thinking is belief in bounded, diachronically continuous selves or subjects. Kantians might agree with this, but many other ethical theorists would not. Some anti-realists would also not agree; but arguably the strongest challenge to Williams's position comes from the kind of moral or ethical realist who holds that certain sorts of valuable experience are so objectively valuable that a subject's diachronic status will often make little or no difference to the value of such experiences. Two completely different kinds of realist fit this description: objectivist utilitarians on the one hand, and on the other, Buddhists who think of the 'experience' of nirvāna in this way. A realism of the latter kind could explain how a bodhisattva's moral aspiration may be justified regardless of how the metaphysics of personhood turns out. But if it turns out that anätman is correct and that ethically salient psychological boundaries are as much intrapersonal as interpersonal (i.e. that there is no ethically relevant difference between the diachronically intrapersonal and the interpersonal, if we can even make this distinction at all), there is no reason why the new psychological framework should not structure or restructure moral considerations that apply in any case - moral considerations such as the importance of overall long-term well-being. Williams seems to have overlooked how a moral or ethical realism of this kind can neutralize his concerns about morally nihilistic tendencies in the anattman framework overlooking this, perhaps, because the kinds of Buddhist philosophy he mainly discusses are anti-realist not only about metaphysical selfhood but also about putative moral properties.

It is not the anatman premise, then, that threatens to undermine the bodhisattva ideal. It could be argued that it does not even pose any acute problems, unless agentrelative moral principles are taken for granted - something even Williams doubts (along with Goodman and Clayton), in Sāntideva's case. What may pose problems, however, for karuṇa , dāna and bodhicitta qua ideals, is moral anti-realism - whether

\footnotetext{
${ }^{44}$ In Part V of Vasubandhu's Madhyānta-Vibhāga-Bhāṣy, where he says: "The highest form [of practise] through continuity is to be known through fulfillment of all the pāramitās of giving, etc. towards all sentient beings without any interruption, the ability for which comes with the confidence that 'self' and 'others' are really the same" (Anacker 1984, 257).
} 
these are problems for defenders of Śāntideva or only certain other Mādhyamikas. However, we have seen that Buddhist ethics has realist options, some of which are 'indigenous', that can - for better or worse - construe these ideals as having a nonrelative value, and restore a kind of normative significance that is not only actionguiding but also value-guided in the justificatory sense.

Returning to the question with which I began this section - whether Buddhist ethics 'requires' moral realism - it is worth qualifying the claim that there are realist 'options' for Buddhist ethics. Three conclusions might be tempting for a Buddhist who rejects moral anti-realism: (1) Buddhist ethics is based on some form of moral realism; (2) Some traditions of Buddhist ethics accept a form or forms of moral realism; and (3) Buddhist ethics is indirectly committed to moral realism. I have argued only for the latter two: (2) on exegetical grounds, and (3) on philosophical grounds. This helps to accommodate, and to respect, the avowals of anti-realism that can be found in the work of many Buddhist ethicists. Nonetheless, realism and antirealism might not be equally viable options, philosophically speaking, for Buddhists. In saying that Buddhist ethics 'has realist options', I meant rather that when Buddhists take seriously the need for a realist framework, there are options for fulfilling that need that derive from (different streams of) the Buddhist tradition itself.

\section{CONCLUDING REMARKS}

In closing, it is worth distinguishing my conclusions from other claims that might (only superficially) resemble them. One, which only needs a brief reprise here, is the claim that some form of moral realism is philosophically the most plausible and defensible meta-ethical view. Rather than defending that claim, I have only argued that many forms of Buddhist ethics and soteriology presuppose that some form of moral realism can be availed of, to make sense of their normative insights.

But two other claims are worth mentioning - as tempting but misleading construals of my conclusions - one more specific than my conclusions, and one more general. The specific claim would be that not only can the general goal(s) of Buddhist ethics be vindicated by moral realism, but also the specific precepts of sila (such as those against killing, theft, and so on), i.e. that these can be treated as absolute normative truths. The more general claim would be that Madhyamaka philosophy, again despite its best interests, flirts with normative collapse not only in meta-ethics and ethics, but also in other areas where justificatory criteria play a role, such as epistemology. From some of my remarks, it may have seemed that I was merely repeating the old concern that Madhyamaka philosophy leaves all of our belief-forming practices in a 'dismal slough' - that is, in a position where even ordinary truths cannot be distinguished from ordinary falsehoods, or from the kinds of obvious myth-making, wishful-thinking, etc., that cognitive improvement (not to mention enlightenment) tries to transcend. The specific claim would have us build on moral realism to arrive at specific moral knowledge. The general claim would have us expand the scope of our critique of Madhyamaka anti-realism. 
Stopping short of endorsing the specific claim, let us recall that it does not follow from a realism about the moral value of compassion (and/or overall well-being) that any particular precept has an unconditionally binding character. It would be compatible with a generic moral realism of the kind considered here to treat a provisional acceptance of precepts as involving a generally upāyic disposition while also acknowledging wise exceptions to precepts as equally upāyic (i.e. skillful means). In a sense, the value of precepts might be relative: it is only relative to the ultimate goal of compassionate, collective engagement that it can be worthwhile to honor a precept, and that same goal can sometimes justify not honoring a precept. But if the importance of the ultimate goal is non-relative, then the relativity of precept-applicability does not amount to moral relativism. (I have suggested, for example, that moral realism would fit well with Goodman's first-order moral theory, which relativizes precept-applicability in this way; i.e., while his theory elevates the significance of teleological priorities, it would subordinate the precepts to those priorities.)

Regarding the general claim, I will merely point out that it invokes a much more general interpretation of Madhyamaka philosophy than I have offered in the form of a critique of a few perspectives on Madhyamaka moral philosophy. It is true that a refutation of moral anti-realism would also be a refutation of global anti-realism; and thus, for those attracted to global anti-realism, the stakes are high in meta-ethics. But I offer no general interpretation of Madhyamaka epistemology here, and am not assuming that it amounts to global anti-realism.

Finally, some might worry that an appeal to moral realism could serve as a Trojan horse for a set of alien expectations about the need for generalized ethical principles or theories in Buddhist ethics. Although I addressed this worry at the outset (noting that moral realists can be particularists, and that some in fact are), it may be worth acknowledging that there is a connection here, albeit nothing as covert as the worry, expressed in that form, suggests. Meta-ethical anti-realists can seek out theoretical interpretations of Buddhist texts, as Goodman's project shows. But the inclination to do this may be stronger among moral realists, even among those whose moral realism is epistemically modest. Such realists do not claim to know which moral claims are true; and since it then becomes important to compare a range of candidates for moral truth, it is inevitable that any sufficiently wide range will include some highly general principles, as well as less 'principled' collections of moral beliefs. This then makes it natural to devote a large part of any intercultural comparative analysis to comparisons guided by familiar theoretical frameworks. This should not load the dice in favor of Western ethical theories; but it can make them useful analytical tools, even in Buddhist ethics. Whether the forms of moral realism and anti-realism familiar in contemporary Western philosophy also serve as analytical tools in this area, and perhaps no more than that, is a question I leave for another occasion. 


\section{ACKNOWLEDGEMENTS}

I wish to thank Bronwyn Finnigan, Jay Garfield, Charles Goodman, Mark Siderits and two anonymous referees of the journal Comparative Philosophy for comments, and Hamid Andishan, Wanekia Dunn, Christopher Framarin, Stephen Harris, Matthew Mackenzie, Richard Mann, Ethan Mills, Emer O’Hagan, Ashwani Peetush, Hari Prasad, Bindu Puri, Noah Quastel, Jonathan Reardon, Mary Renaud, Noel Salmond, Sonia Sikka, Shweta Singh, Angela Sumegi, and Ajay Verma for many related discussions.

\section{REFERENCES}

Anacker, Stefan (trans./ed.) (1984), Seven Works of Vasubandhu (Delhi: Motilal Banarsidass).

Audi, Robert (2005), The Good in the Right: A Theory of Intuition and Intrinsic Value (Princeton: Princeton University Press).

Barnhart, Michael G. (2012), "Theory and Comparison in the Discussion of Buddhist Ethics", Philosophy East and West, 62 (1): 16-43.

Baron-Cohen, Simon (2011), The Science of Evil: On Empathy and the Origins of Cruelty (New York: Basic Books).

Burton, David (2004), Buddhism, Knowledge and Liberation: A Philosophical Study (Aldershot: Ashgate).

Clayton, Barbra (2006), Moral Theory in Śāntideva's Śikṣāsamuccaya: Cultivating the Fruits of Virtue (London: Routledge).

Collins, Steven (1998), Nirvana and other Buddhist Felicities (Cambridge: Cambridge University Press).

Cuneo, Terence (2007), The Normative Web: An Argument for Moral Realism (Oxford: Oxford University Press).

Dancy, Jonathan (2000), Practical Reality (Oxford: Oxford University Press).

Dancy, Jonathan (2004), Ethics without Principles (Oxford: Clarendon Press).

Davids, C.A.F. Rhys (1978), The Birth of Indian Psychology and its Development in Buddhism (New Delhi: Oriental Books Reprint Corp.).

Davis, Gordon (2013). "Traces of Consequentialism and Non-Consequentialism in Bodhisattva Ethics", Philosophy East and West, 64 (2): 275-305.

Dreyfus, Georges (2011), "Can a Mādhyamika be a Skeptic? The Case of Patsab Nyimadrak", in G. Dreyfus et al. (the Cowherds), Moonshadows: Conventional Truth in Buddhist Philosophy (Oxford: Oxford University Press), 89-113.

Dumoulin, Heinrich (2005), Zen Buddhism: A History - Volume 1: India and China, revised edition, trans. J. Heisig \& P. Knitter, (Bloomington: World Wisdom).

Enoch, David (2011), Taking Morality Seriously: A Defence of Robust Realism (Oxford: Oxford University Press).

Finnigan, Bronwyn (2010), "Buddhist Meta-Ethics", Journal of the International Association of Buddhist Studies, 33: 267-297. 
Finnigan, Bronwyn (2011), "How can a Buddha Come to Act? The Possibility of a Buddhist Account of Ethical Agency", Philosophy East and West, 61: 134-160.

Finnigan, B. \& Tanaka, K. (2011a), "Carnap's Pragmatism and the Two Truths", in Dreyfus et al. (the Cowherds), Moonshadows: Conventional Truth in Buddhist Philosophy (Oxford: Oxford University Press), 181-188.

Finnigan, B. \& Tanaka, K. (2011b), "Ethics for Mādhyamikas", in Dreyfus et al. (the Cowherds), Moonshadows: Conventional Truth in Buddhist Philosophy (Oxford: Oxford University Press), 221-231.

Garfield, Jay (2000), "Particularity and Principle: The Structure of Moral Knowledge", in B. Hooker \& M.O. Little (eds.), Moral Particularism (Oxford: Clarendon), 178-204.

Garfield, Jay (2002a), "Three Natures and Three Naturelessnesses: Comments Concerning Cittamatra Conceptual Categories", in Garfield, Empty Words: Buddhist Philosophy and Cross-Cultural Interpretation (Oxford: Oxford University Press).

Garfield, Jay (2002b), "Sounds of Silence: Ineffability and the Limits of Language in Madhyamaka and Yogācāra", in Garfield, Empty Words: Buddhist Philosophy and Cross-Cultural Interpretation (Oxford: Oxford University Press).

Garfield, Jay (2002c), "Vasubandhu's Treatise on the Three Natures: A Translation and Commentary", in Garfield, Empty Words: Buddhist Philosophy and CrossCultural Interpretation (Oxford: Oxford University Press).

Garfield, Jay (2002d), "Western Idealism through Indian Eyes", in Garfield, Empty Words: Buddhist Philosophy and Cross-Cultural Interpretation (Oxford: Oxford University Press).

Garfield, Jay (2011), "Hey, Buddha! Don't Think! Just Act! A Response to Bronwyn Finnigan." Philosophy East and West, 61: 174-183.

Garfield, Jay (forthcoming), "Buddhist Ethics in the Context of Conventional Truth: Path and Transformation".

Gethin, Rupert (1998), The Foundations of Buddhism (Oxford: Oxford University Press).

Gethin, Rupert (trans./ed.) (2008), Sayings of the Buddha: A Selection of Suttas from the Pali Nikāyas (Oxford: Oxford University Press).

Goodman, Charles (2009), The Consequences of Compassion: An Interpretation and Defence of Buddhist Ethics (Oxford: Oxford University Press).

Hallisey, Charles (1996), "Ethical Particularism in Theravāda Buddhism", Journal of Buddhist Ethics, 3: 32-43.

Hampton, Jean (1998), The Authority of Reason (Cambridge: Cambridge University Press).

Horgan, T. \& Timmons, M. (1991), "New Wave Moral Realism Meets Moral Twin Earth", Philosophy and Phenomenological Research, 16: 447-465.

Horgan, T. \& Timmons, M. (2006), "Morality without Moral Facts", in J. Dreier (ed.), Contemporary Debates in Moral Theory (Oxford: Blackwell), 220-238. 
Huntington, C.W. Jr., with G.N. Wangchen (1989), The Emptiness of Emptiness: An Introduction to Early Indian Mãdhyamika (Honolulu: University of Hawaii Press).

Kagan, Shelly (2000), "Evaluative Focal Points", in B. Hooker, E. Mason \& D.E. Miller (eds.), Morality, Rules and Consequences (Edinburgh: Edinburgh University Press), 134-155.

Kagan, Shelly (2009), "Well-Being as Enjoying the Good", Philosophical Perspectives, 23: 253-272.

Kalupahana, David (1995), Ethics in Early Buddhism (Honolulu: University of Hawaii Press).

Kapstein, Matthew (2001), Reason's Traces: Identity and Interpretation in Indian and Tibetan Buddhist Thought (Boston: Wisdom Publications).

Keown, Damien (2001), The Nature of Buddhist Ethics, $2^{\text {nd }}$ ed. (New York: Palgrave).

Kochumuttom, Thomas A. (1982), A Buddhist Doctrine of Experience: A New Translation and Interpretation of the Works of Vasubandhu the Yogācārin (Delhi: Motilal Banarsidass).

Lusthaus, Dan (2002), Buddhist Phenomenology: A Philosophical Investigation of Yogācāra Buddhism (London: Routledge).

McDowell, John (1998), Mind, Value and Reality (Cambridge, Mass: Harvard University Press).

McNaughton, D. \& J.P. Rawling (2003), "Naturalism and Normativity", Supplement to the Proceedings of the Aristotelian Society, 77: 23-45.

Moore, G.E. (1903), Principia Ethica (London: Cambridge University Press).

Nietzsche, Friedrich (1966), Beyond Good and Evil, trans. W. Kaufmann (New York: Vintage).

Oddie, Graham (2005), Value, Reality and Desire (Oxford: Oxford University Press).

Parfit, Derek (2011), On What Matters (Oxford: Clarendon Press).

Premasiri, P.D. (1997), "Ideas of the Good in Buddhist Philosophy”, E. Deutsch \& R. Bontekoe (eds.), A Companion to World Philosophies (Oxford: Blackwell), 349359.

Prinz, Jesse (2007), The Emotional Construction of Morals (Oxford: Oxford University Press).

Railton, Peter (2003), Facts, Values and Norms: Essays toward a Morality of Consequence (New York: Cambridge University Press).

Sāntideva (1995), The Bodhicaryāvatāra, trans. K. Crosby \& A. Skilton (Oxford: Oxford University Press).

Shafer-Landau, Russ (2003), Moral Realism: A Defence (Oxford: Oxford University Press).

Shields, James M. (2011), Critical Buddhism: Engaging with Modern Japanese Buddhist Thought (Surrey, UK: Ashgate).

Siderits, Mark (2003), "On the Soteriological Significance of Emptiness", Contemporary Buddhism, 4: 9-23. 
Siderits, Mark (2006), "Buddhist Reductionism and the Structure of Buddhist Ethics", in P. Bilimoria, J. Prabhu \& R. Sharma (eds.), Indian Ethics: Classical and Contemporary Challenges (Aldershot: Ashgate), 283-95.

Vasubandhu (1984), Madhyānta-Vibhāga-Bhāșya, trans. S. Anacker, in Anacker (ed.), Seven Works of Vasubandhu (Delhi: Motilal Banarsidass).

Velez de Cea, Abraham (2004), "The Criteria of Goodness in the Pāli Nikayas and the Nature of Buddhist Ethics", Journal of Buddhist Ethics, 11: 123-142.

Wallis, G. (trans./ed.) (2004), The Dhammapada: Verses on the Way (New York: Modern Library).

Webster, David (2005), The Philosophy of Desire in the Buddhist Pali Canon (London: Routledge).

Wedgwood, Ralph (2007), The Nature of Normativity (Oxford: Oxford University Press).

Williams, Paul (1998), Altruism and Reality: Studies in the Philosophy of the Bodhicaryavatara (Surrey, UK: Curzon Press).

Williams, Paul (2009), Mahāyāna Buddhism: The Doctrinal Foundations, $2^{\text {nd }}$ ed. (London: Routledge).

Wittgenstein, Ludwig (1953), Philosophical Investigations, trans. G.E.M. Anscombe (Oxford: Blackwell).

Wright, Dale S. (2006), "Satori and the Moral Dimension of Enlightenment", Journal of Buddhist Ethics, 13: 1-22. 